\title{
Quantitative mapping of specific proteins in biological tissues by laser ablation-ICP-MS using exogenous labels: aspects to be considered
}

\author{
María Cruz-Alonso ${ }^{1}$, Ana Lores ${ }^{1}$, Eva Valencia ${ }^{1}$, Héctor González-Iglesias ${ }^{2,3 *}$, \\ Beatriz Fernández ${ }^{1,3} *$ and Rosario Pereiro ${ }^{1,3}$
}

${ }^{1}$ Department of Physical and Analytical Chemistry, University of Oviedo, Julian Clavería 8, 33006 Oviedo, Spain

${ }^{2}$ Instituto Oftalmológico Fernández-Vega, Avda. Dres. Fernández-Vega, 34, 33012 Oviedo, Spain.

${ }^{3}$ Instituto Universitario Fernández-Vega (Fundación de Investigación Oftalmológica, Universidad de Oviedo), Spain.

* Authors to whom correspondence should be addressed: fernandezbeatriz@uniovi.es \& h.gonzalez@fio.as

To be included in the Special Issue "Elemental \& Molecular Imaging by LA-ICP-MS", 


\begin{abstract}
Laser ablation (LA) coupled to ICP-MS is regarded as a versatile tool for direct trace elemental and isotopic analysis of solids. The development of new strategies for quantitative elemental mapping of biological tissues is one of the growing research areas in LA-ICP-MS. On the other hand, latest advances are related to obtaining not only elemental distribution of heteroatoms but also molecular information. In this vein, mapping of specific proteins in biological tissues can be carried out with LA-ICP-MS by using metal-labelled immunoprobes. However, although LA-ICP-MS is in principle a quantitative technique, critical requirements should be met for absolute quantification of protein distribution. In this review, progress based on the use of metal-labelled antibodies for LA-ICP-MS mapping of specific proteins are tackled. Critical requirements to obtain absolute quantitative mapping of specific proteins by LA-ICPMS are highlighted. Additionally, illustrative examples with the advances carried out so far using LA-ICP-MS are collected.
\end{abstract}

Keywords: immunohistochemistry, antibody labelling, laser ablation, ICP-MS, protein quantification 


\section{Introduction}

Nowadays increasing research effort is addressed towards the study of proteins to understand their biological funtions. The great analytical challenge in this area is to combine specificity (biological samples are complex matrices), high sensitivity (the species of interest can be at very low concentration levels) and absolute quantitative information (i.e. the capability to assess not only differential protein expression between two samples, but also protein absolute quantities) [1,2]. Optical-spectroscopy and mass spectrometry (MS) techniques offer interesting capabilities within this field for liquid samples and for chemical imaging of solid specimens $[3,4]$.

In particular, molecular MS techniques with soft-ionization sources, such as electrospray ionization (ESI) and matrix-assisted laser desorption/ionization (MALDI) are commonly used in protein analysis. However, although several technical and methodological improvements have been developed to remove or circumvent limitations [5,6], MALDI- and ESI-MS are typically not considered for absolute quantification purposes. On the other hand, elemental MS, and particularly the inductively coupled plasma (ICP) ion source, can facilitate the quantitative research in life sciences. Low detection limits, wide linear dynamic range, elemental specificity, multi-element (and multi-isotope) analysis, and virtual species- and matrix-independent ionization, are among the main analytical features of ICP-MS. Such performances are of particular interest to obtain absolute concentrations of biomolecules in complex samples without the need of specific standards $[1,7]$.

Absolute protein quantification using ICP-MS can be carried out by direct measurement of many proteins through naturally present heteroatoms such as $\mathrm{S}, \mathrm{Se}, \mathrm{P}$ and metals; however, in this case it is required that the sought protein is carefully isolated from the sample matrix. Additionally, exogenous elemental (or isotopic) labelling of biomolecules makes almost all proteins ICP-MS-detectable. I [8], Fe [9], $\mathrm{Hg}[10]$ or lanthanides [11,12] have been used to directly label the analyte for ICP-MS quantification, with different degree of success; such direct labelling strategies require the careful isolation of a given target biomolecule with appropriate separation techniques (e.g. liquid chromatography or gel electrophoresis) prior to the detection step. As a step forward, pioneering experiments at the beginning of this century [13-15] were carried out making use of specific immunochemical reactions between the sought species and a metal-labelled antibody. Although the approach is not ideal because it has the typical drawbacks related to the use of antibodies [16], it is fair to say that it has 
opened new perspectives in specific and multiplexed protein quantification by ICP-MS [17-20]. Single metal chelates [21], polymers containing several chelates [22] and metal nanoparticles (NPs) [14,23] have been proposed as chemical reporters to label the antibody to be used in the immunochemical reaction.

In the case of chemical imaging by ICP-MS, maps of specific proteins in biological tissues can be obtained using laser ablation (LA) sampling after an immunohistochemistry (IHC) protocol with metal-labelled antibodies [24]. LA-ICP-MS is currently regarded as a versatile MS tool for trace (element and isotopic) direct analysis of solids, offering quantitative capabilities [25]. Moreover, LA-ICP-MS allows high spatial resolution (typically $>1 \mu \mathrm{m}$ ) and, with the development of faster ablation cells [26,27], well resolved images of the specimen can be obtained in rather shorttimes. In addition, the use of mass analysers with quasi-simultaneous spectral acquisition capabilities, such as the time of flight (TOF), allows for multielemental (hyperspectral) imaging [28,29]; unfortunately, sensitivity of TOFMS analysers is not as high as compared with other MS systems, particularly for lighter elements. Nowadays, LA-ICP-MS is being used for a wide range of different analysis, and a main area of interesting applications of LA-ICP-MS lies in the biomedical field [25,30-32].

Several approaches based on the use of metal-labelled antibodies have been developed for simultaneous mapping of specific proteins by LA-ICP-MS, constituting an interesting alternative to commonly used fluorescence detection. Fluorescent labels with different emission lines have enabled multiplexed fluorescence analysis. Unfortunately, the development of highly multiplexed assays is hampered by the dyes bandwidth (i.e. the potential spectral overlap), the difficulty in measuring simultaneously targets that differ in abundance by an order of magnitude or more, and the risks of dye fluorescence quenching. In the case of biological tissues and cells, (IHC) imaging based on fluorescence measurements is, in addition, limited by sample autofluorescence, signal scattering and lack of robust quantification procedures [33,34].

However, although expectations for LA-ICP-MS specific protein mapping are high, some issues should be addressed to achieve absolute quantification of the specific proteins maps within the biological tissue. Below are collected a summary of the challenges to face for absolute quantitative mapping as well as the advances carried out so far using LA-ICP-MS. 
Critical requirements for absolute quantitative mapping of specific proteins by LA-ICP-MS

Quantitative elemental information of heteroatoms naturally present in biological tissues can be achieved by LA-ICP-MS by resorting to appropriate calibration standards (e.g. homogenized and spiked tissues, agarose gels, gelatin and polymeric films) [25,30-35]. However, the analytical concept is more complex in the case of proteins. Mapping of specific proteins by LA-ICP-MS requires the use of proper labelled antibodies and the development of IHC protocols [36]. In principle, such protocols can be similar than those used in conventional immunofluorescence and immunoperoxidase staining, excepting that the label (chemical reporter) should contain an element (or isotope) detectable by ICP-MS. In addition, special care should be taken when using conventional IHC protocols, because the microchemical composition can be altered during the sample preparation procedure (e.g., formalin fixation and paraffin embedding) [3,37].

Figure 1 shows the steps of two general IHC protocols for LA-ICP-MS mapping of biomolecules. Tissue sections (a few $\mu \mathrm{m}$ thick) from formalin-fixed paraffinembedded blocks are mounted on IHC microscope slides. After paraffin removal, a surfactant is added to the slides. A further washing step is necessary, and then a blocking agent solution is added for a certain period of time. Then, depending of the selected procedure, two different protocols ( $\mathrm{a}$ or b) can be followed: (a) The labelled primary antibody is added and incubated. After incubation, a washing step is done and the specimen is then ready for LA-ICP-MS measurement. (b) After incubation with a primary antibody, a washing step is performed and then a labelled secondary antibody (which recognizes the unlabelled primary antibody) is added and incubated; a final washing step is carried out, and the specimen is then submitted to LA-ICP-MS analysis. Each of both alternatives has inherent advantages: labelled primary antibodies offer higher specificity and greater potential for multiplexing, while the use of labelled secondary antibodies allows for higher sensitivity and may be used as generic platform [3].

Studies aiming at quantitative mapping of biomolecules in tissue sections by LAICP-MS are still scarce. The use of a homogeneously distributed internal standard should correct for variation in laser power, changes in transport, drift in the plasma sensitivity as well as for the ablated mass introduced into the ICP-MS. Several internal standardisation strategies have been proposed within this context, such as iodination to 
correct for tissue inhomogeneities [38]; unfortunately, iodine has some limitations such as a long wash-out (memory effects). Also, labelling with an Ir intercalator that targets nuclei has been proposed [39]; unfortunately, this strategy can be only used for low resolution imaging because at the $5 \mu \mathrm{m}$ resolution level certain structures in the intensity were recognized. Printing of metal spiked inks onto tissue sections has been also proposed for internal standardization [40]. Moreover, Mueller et al. [41] presented an interesting approach, using lanthanide-labelled antibodies, for quantitative immunoimaging of single eukaryotic cells; the calculation of an exact labelling degree as well as the correlation factor between amount of lanthanide per cell and amount of antibodyantigen complex were reported as critical aspects for further optimization.

In this context, there is still a lack of reliable and universal quantification strategies of protein images within tissues by LA-ICP-MS after IHC protocols. In Table 1 are identified ten general points ("golden rules") which should be carefully considered in the development of a method for absolute quantitative mapping of specific proteins in biological tissues by elemental MS. First, it is necessary to keep in mind that to avoid risks of signal background from the sample it is recommended that the elements (or isotopes) used for labelling should not be present at detectable concentrations in the biological tissue. Rare earth elements, $\mathrm{Au}, \mathrm{Ag}, \mathrm{Pt}$ or Ir are examples of elements of choice. The use of monoisotopic elements such as $\mathrm{Au}$ will allow for higher amplification with cheaper labels. Conversely, isotopically enriched stable elements will be more expensive but would allow for higher multiplexing capabilities.

The next aspect to be considered is related to the label size. Small labels should be employed to prevent size impediments, since big labels have higher risk of blocking active sites in the antibody or will make the bioconjugate too big to properly penetrate in the tissue section. On the opposite, to get signal amplification (i.e., high sensitivity for protein detection) it is required a high number of atoms of the element (or isotope) per label. Therefore, a compromise should be taken regarding label size: optimum labels will be those having a high ratio of number of atoms of the sought element (or isotope) per label size. Another point related with label requirements is to know, as accurately as possible, the number of atoms of the detected element (or isotope) per label. Moreover, the concentration of the label in the solution for antibody labelling should be known.

Regarding the bioconjugation procedure of the metal label with the antibody, it is necessary to keep in mind that experimental conditions should be as mild as possible to prevent risks related to antibody degradation. Moreover, binding properties of 
antibodies may be altered during labelling. Therefore, labelling compromise conditions are required to get effective labelling without affecting the binding properties and the specificity of the antibody (i.e. it is convenient to use physiological labelling conditions). One of the critical points is the labelling yield. If the labelling is not complete (close to $100 \%$ yield) at least the labelling degree must be reproducible and must be known for accurate quantification. Also, the labelled antibody should preferably be stable under different $\mathrm{pH}$ conditions and salt concentrations.

Once the labelling of the antibody has taken place, unconjugated antibodies should not be present in the solution employed for IHC (their presence will produce incorrect results since antibodies not detectable by ICP-MS can be connected with the sought analyte). This can be achieved by using the antibody as limiting reactant in the labelling procedure of the antibody, or by removing the excess of unconjugated antibody (e.g. by chromatography or ultrafiltration) prior to the IHC protocol. On the other hand, care should be taken to avoid aggregation of the labelled antibodies. Gel electrophoresis, fluorescence microscopy and electron microscopy techniques can be used to assess aggregation. In addition, the number of labels per available antibody (stoichiometry) should be known. For such purpose, both the label concentration in the purified bioconjugate solution and the available antibody concentration should be defined. Here, it is important to highlight that the determination of total protein per bioconjugate unit will not provide enough information because during the bioconjugation process some antibody molecules could be partially degraded or impeded for interaction with the analyte. Therefore, the immunoreactivity of the labelled antibody should be calculated with an ELISA experiment. On the other hand, concentration of the heteroatom label in the labelled antibody can be calculated, for example, by ICP-MS.

Regarding the IHC procedure and to facilitate a quantitative interaction between the labelled antibody and the target molecule in the biological tissue, the sample should be thin enough (i.e. a few microns) to ensure full labelled antibody penetration in the sample tissue. A probably more important factor is that the labelled antibody should be in excess and the interaction with the specimen should be maintained during a time long enough (overnight incubation is typically used to ensure complete tissue penetration and the most common dilution for antibodies is in the range of 1:1000 to 1:5000). Finally, the excess (unreacted) of labelled antibody must be efficiently removed. 
To end with, the use of an elemental mass detection system with high sensitivity, structure-independent response and wide dynamic linear range (i.e. LA-ICP-MS) will be most convenient. Here, special attention should be paid to proper calibration using suitable matrix-matched standards and, preferably, internal standardization as well.

\section{Labels used for protein mapping of specific proteins by LA-ICP-MS}

Proteins contain several reactive groups which can be used as targets for modifications by chemical labelling $[42,43]$. For example, amino groups react with isothiocyanate and N-hydroxysuccinimide (NHS) functionalities. For labelling thiol groups of reduced cysteine residues, maleinimides and halogenacetamides can be used. Carboxyl-reactive chemical groups in biomolecular probes can be used also for labelling through carbodiimide chemistry by crosslinking carboxylic acids to primary amines. Clickchemistry can be employed for labelling after artificial introduction of azide or alkyne moieties into the proteins. Several strategies and label-types have been proposed for heteroatom labelling in immunoassays. Below they will be briefly reviewed focusing in those published with LA-ICP-MS detection.

Most LA-ICP-MS applications deal with labels containing only one detectable element/isotope. Diethylenetriaminepentaacetic acid (DTPA) (Figure 2a) and the macrocycle 1,4,7,10-tetraazacyclododecane-1,4,7,10-tetraacetic acid (DOTA) (Figure 2b) [21] form strong complexes with metals and can be used as antibody labels. High multiplexing and quantification capabilities are main advantages brought about by such combination. To be used as labels, they should contain, additionally, a reactive group which binds covalently to antibodies. Furthermore, labels with a high number of detectable elements/isotopes (e.g. polymers, NPs) have been also proposed aiming at signal amplification and, therefore, to increase sensitivity for protein detection.

Labels with one detectable element/isotope atom. Single metal chelates, and specially the macrocyclic DOTA coordinated with heteroatoms (typically lanthanide ions which have high complexation affinities to DOTA and low natural background in biological samples), have been widely employed for elemental/isotopic labelling [21,44]. As indicated above, to be of use for antibody labelling they should contain a reactive residue. Varied bi-functional DOTA molecules have been developed. Among the most commonly groups employed for such purposes are isothiocyanatobenzyl (bz-SCN) and 
maleimide (see Figures 2c and 2d) [21,45,46]. Depending on the linking chemistry, an average between 1 and 4 detectable atoms per antibody are introduced [20].

Bz-SCN-DOTA lanthanide complexes [47], which bind to lysine residues, have been applied in several LA-ICP-MS applications, such as the multi-parametric analysis of cytochrome P450 isoenzymes after electrophoretic separation and blotting [48], or the multiplexed IHC detection of Her 2, CK7 and MUC1 tumour markers in breast cancer tissue by labelling anti-Her 2, anti-CK7, and anti-MUC1 with $\mathrm{Ho}, \mathrm{Tm}$, and $\mathrm{Tb}$ Bz-SCN-DOTA complexes (see Figure 3) [44]. Unfortunately, it has been shown that bz-SCN-DOTA do not leads to one kind of labelled antibody molecule. Instead, a label distribution and a high percentage of unmodified molecules (reported labelling yield is as low as 0.03) could occur [49].

Another common labelling strategy resorts to a maleimide linker, which binds covalently to sulfhydryl residues (such as maleimido-mono-amide-DOTA [50] and the Metal-code affinity tags or MeCATs [45,51]). In this case, reduction of disulfide bridges is a necessary step. For a suitable labelling, the challenge is to reduce as many disulfide bonds of the antibody as possible to produce reaction sites for the maleimide group without affecting the binding capability of the antibody [49]. Application examples of maleimide-DOTA related compounds include the multiplexed analysis of plant thylakoid proteins on western blots [50] and the development of a multiparametric microarray for simultaneous analysis of 8 different cytochromes [51]. Labelling efficiency is higher than in the case of bz-SCN-DOTA [49], however, it has been reported severe risks of high complexity of the metal-labelled antibody. In fact, it has been shown that antibody fragments of different sizes and labelling degrees were obtained following the chemistry required for maleimide-DOTA labelling [52]. This prevents the development of a quantification procedure because the calculation of antibody molecules in the sample is not possible. As alternative, it has been proposed a labelling concept resulting in one label per antibody. The strategy is based on the previous modification of small antibody binding domains, $\mathrm{C} 2_{\mathrm{Fc}}$ and $\mathrm{C} 2_{\mathrm{Fab}}$, with a metal maleimide-DOTA compound. Antibodies are then labelled with these modified C2 domains by mixing and subjecting them to far-UV light [53].

Highly-amplified label methodologies for protein analysis by LA-ICP-MS. Polymeric labels containing several metal chelates of a given metal or isotope provide noticeable signal amplification $[22,28,29,54]$. Here, it should be highlighted the commercially 
available MAXPAR ${ }^{\mathrm{TM}}$ labelling kits containing DTPA chelating compounds. Nowadays two polymer types are commercially available: the $7 \mathrm{~nm}$-long linear $\mathrm{X} 8$ polymer containing about 22 chelators/polymer and the branched DN3 polymer with $5 \mathrm{~nm}$ diameter and containing about 16 chelators/polymer. The metal polymeric label is bound to the antibody through a maleimide linker, using disulfide reduction. Typically, 4-5 of such polymers will be conjugated to each antibody [19].

These polymers have been successfully used as antibody labels in varied applications, mostly in combination with ICP-TOFMS for mass cytometry [19] where it has shown an outstanding value. In addition, the strategy has been coupled to LA for imaging mass cytometry [28] and for highly multiplexed imaging of tissues at subcellular resolution. Here, it is worth to highlight the pioneering work by Giesen et al. [29] where simultaneous imaging of 32 target biomolecules (proteins and protein modifications) was achieved using polymers containing rare earths as reporters on antibodies. However, the polymeric non-metallic part of these labels gives room for improvement of the ratio "number of detectable metal atoms per label size". Moreover, risk of non-specific interactions has been reported in the case of the IHC procedures in biological tissues [49].

Finally, antibodies labelled with metal NPs have proved to be another interesting strategy for immunoassays detection in liquid samples by ICP-MS [14,23]. In the case of LA-ICP-MS, the use of antibodies labelled with metallic NPs is still scarce. For instance, $10 \mathrm{~nm}$ size Au NPs were employed in blotting membranes after protein separation by SDS-PAGE [55]. Bioimaging experiments were carried out for breast cancer biomarkers using $5 \mathrm{~nm}$ Au NPs labelled secondary antibody [56]. In addition, this protein labelling approach, based on the use of a secondary IgG antibody (labelled in this case with $10 \mathrm{~nm} \mathrm{Au} \mathrm{NPs),} \mathrm{was} \mathrm{employed} \mathrm{for} \mathrm{bioimaging} \mathrm{tyrosine} \mathrm{hydroxylase}$ (rate-limiting enzyme in dopamine biosynthesis) in mice brain [57,58].

Recent advances in nanotechnology have introduced a new class of fluorescent labels, named as fluorescent metal nanoclusters (NCs), with sizes between 0.2 and $3 \mathrm{~nm}$ (this type of nanostructures is characterized by sizes comparable to the Fermi wavelength of electrons and, therefore, they can exhibit molecule-like properties) [59]. These NCs are composed of a few to several hundred metal atoms and the surface of the nanostructure can be tailored with selected groups for different chemistries [60]. Gold nanoclusters ( $\mathrm{Au} \mathrm{NCs}$ ) exhibit strong fluorescence, good photostability and biocompatibility. Therefore, they constitute a promising alternative to more conventional 
luminescent markers used in the bioanalytical field [61]. Moreover, these small labels can provide signal amplification as elemental labels in LA-ICP-MS bioimaging. In addition, there will be no accessibility restrictions to the target protein within the tissue (this is one of the problems associated with larger labels). Finally, Au NCs will allow for sequential bimodal detection (fluorescence by microscopy and elemental/isotopic by LA-ICP-MS) in the same sample spot. Recently, the proof of concept has been demonstrated for the mapping of metallothioneins in the human retina (see Figure 4) using water-soluble $\mathrm{Au} \mathrm{NCs}$ with an average size of $2.7 \mathrm{~nm}$ and more than $500 \mathrm{Au}$ atoms per label [24]. In such example, carboxylic groups of the AuNCs surface were bioconjugated with specific primary antibodies by carbodiimide coupling. This format offers advantages as compared to the use of a secondary antibody labelled (with $\mathrm{Au}$ NPs) above described [56-58], such as higher multiplexing capabilities using a different type of metal NC per specific primary Ab. Moreover, this format can be further extended to nanoclusters of other metals, such as Ag [62] or Pt [63]. This opens the door for the synthesis of isotopically-enriched metal NCs (thus increasing the palette of chemical reporters for antibody labelling compared to the monoisotopic Au NCs).

\section{Conclusions}

There is no doubt that the combination of IHC with spectroscopic and MS techniques offers great possibilities for quantitative imaging of specific proteins in biological tissues, with detailed aid in experimental design provided in previous reviews [3].

In particular, the combination of LA-ICP-MS with IHC offers great interest for chemical imaging of specific proteins. For example, within this context it is worth to point out that the use of antibodies labelled with metal isotopes (e.g. lanthanides) and rapid-response ablation cells combined with ICP-TOFMS allows for amazing hyperspectral capabilities for fast multi-protein imaging [2938].

As it is known, any increase in spatial resolution with LA-ICP-MS implies lower sensitivity. Therefore, labels providing signal amplification (e.g. several metal atoms per label) are most convenient to obtain highly-resolved images, such as the MAXPAR $^{\mathrm{TM}}$ and the metal NCs. Here, studies should aim at selecting a compromise between number of metal atoms and label size: labels with a high number of metal atoms will provide high signal amplification, but the limit will be given by steric impediments with the antibody. On the other hand, it should be highlighted the interest 
of developing labels for multimodal imaging detection (e.g. fluorescence and MS), allowing to obtain complementary analytical information [24,64,65]. Additionally, though fluorescence measurements are more prone to troubling effects (e.g. autofluorescence and signal scattering), they are typically cheaper and faster than conventional LA-ICP-MS. Therefore, these dual probes can serve both for optimization of the method and for a first test of the samples after the IHC protocol before measurement by LA-ICP-MS.

LA-ICP-MS is an intrinsically quantitative technique. However, to obtain absolute quantitative information of protein maps by LA-ICP-MS after an IHC protocol is not an easy task because different requirements (considered in the previous sections) should be fulfilled along the whole procedure. Probably the most critical one to achieve a reliable absolute quantitative IHC image by LA-ICP-MS is to ensure a controlled chemistry for antibody metal labelling. In this vein, new interesting approaches have been recently proposed $[53,66]$ but it would be of high value a further intense collaborative work between specialists of different fields to achieve more progresses in this direction.

Finally, it is worth to mention that research in this field can be extended to other cutting edge studies, such as the elucidation of mechanisms related with antibody-drug conjugates for oncology therapeutics [67,68], as well as for nucleic acids (DNA and RNA) assays [69].

\section{Acknowledgements}

This work was supported through project CTQ2016-79015-R by Agencia Estatal de Investigación (Spain) and FEDER. B. Fernandez acknowledges her contract RYC-201414985 to the Spanish Ministry of Economy and Competitiveness through the "Ramón y Cajal Program". The Instituto Oftalmológico Fernández-Vega and Fundación de Investigación Oftalmológica acknowledge support from "Cátedra Rafael del Pino" (Fundación Rafael del Pino), and Instituto de Desarrollo Económico del Principado de Asturias (IDEPA) of Principado de Asturias and FEDER (project IDE/2016/000214). 


\section{LEGENDS OF FIGURES}

Figure 1. Main steps of IHC protocols required for LA-ICP-MS analysis of biological tissue sections. (a) Primary antibody labelled with the selected elemental/isotopic label, and (b) Secondary antibody labelled with the selected elemental/isotopic label.

Figure 2. Chemical formula of DTPA and DOTA chelating compounds and of frequent group-types for linking to antibody residues used in combination with LA-ICP-MS detection. (a) DTPA, (b) DOTA, (c) Bz-SCN, and (d) Maleimide.

Figure 3. Immunohistochemical staining of $3 \mu \mathrm{m}$ thick breast cancer tissue sections, positive for (a) Her 2, and (b) CK 7. LA-ICP-MS images are observed at the left of Figures a and b. Laser spot size $200 \mu \mathrm{m}$. Characteristic microscopic findings are highlighted by black frames. From reference [44] with permission of American Chemical Society. Copyright (C) 2011.

Figure 4. Dual study of MT1/2 distribution in neurosensory retina of eye tissue section after immunohistochemistry with AuNC bioconjugate (MT 1/2) by fluorescence and LA-ICP-MS. a) Transmission image for the analysed area, b) AuNCs-Antibody bioconjugate fluorescence by confocal microscopy, and c) Qualitative image obtained by LA-ICP-MS (4 $\mu \mathrm{m}$ spot size) for ${ }^{197} \mathrm{Au}^{+}$(i.e. MT1/2) distribution. From reference [24] with permission of Springer. Copyright (C) 2018. 


\section{References}

1. Calderón-Celis F, Ruiz Encinar J, Sanz-Medel A. Standardization approaches in absolute quantitative proteomics with mass spectrometry. Mass Spec Rev 2017;1-23. doi: 10.1002/mas.21542

2. Cid-Barrio L, Calderón-Celis F, Abásolo-Linares P, Fernández-Sánchez ML, CostaFernández JM, Ruiz Encinar J, Sanz-Medel A. Advances in absolute protein quantification and quantitative protein mapping using ICP-MS. Trends in Anal Chem 2018;104:148-59. doi: 10.1016/j.trac.2017.09.024

3. Bishop DP, Cole N, Zhang T, Doble PA, Hare DJ. A guide to integrating immunohistochemistry and chemical imaging. Chem Soc Rev 2018;47: 3770-87. doi: 10.1039/C7CS00610A

4. Sancey L, Motto-Ros V, Busser B, Kotb S, Benoit JM, Piednoir A, Lux F, Tillement O, Panczer G, Yu J. Laser spectrometry for multi-elemental imaging of biological tissues. Scientific reports 2014;4:6065. doi: 10.1038/srep06065

5. Rzagalinski I, Volmer DA. Quantification of low molecular weight compounds by MALDI imaging mass spectrometry - A tutorial review. Biochim Biophys Acta 2017; 1865:726-39. doi: 10.1016/j.bbapap.2016.12.011

6. Higashi T, Ogawa S. Isotope-coded ESI-enhancing derivatization reagents for differential analysis, quantification and profiling of metabolites in biological samples by LC/MS: A review. J Pharm Biomed Anal 2016;130:181-93. doi: 10.1016/j.jpba.2016.04.033

7. Sanz-Medel A, Montes-Bayón M, Bettmer J, Fernández-Sanchez ML, Ruiz Encinar J. ICP-MS for absolute quantification of proteins for heteroatom-tagged, targeted proteomics. Trends in Anal Chem 2012;40:52-63. doi: 10.1016/j.trac.2012.07.020

8. Jakubowski N, Messerschmidt J, Anorbe MG, Waentig L, Hayen H, Roos PH. Labelling of proteins by use of iodination and detection by ICP-MS. J Anal At Spectrom 2008;23:1487-96. doi: 10.1039/b718074h

9. Bomke S, Pfeifer T, Meermann B, Busche W, Karst U. Liquid chromatography with complementary electrospray and inductively coupled plasma mass spectrometric detection of ferrocene labelled peptides and proteins. Anal Bioanal Chem 2010;397:3503-13. doi: 10.1007/s00216-009-3123-Z

10. Kutscher DJ, del Castillo Busto ME, Zinn N, Sanz-Medel A, Bettmer J. Protein labelling with mercury tags: fundamental studies on ovalbumin derivatised with p- 
hydroxymercuribenzoic acid (pHMB). J Anal At Spectrom 2008;23:1359-64. doi: $10.1039 / \mathrm{b} 806118 \mathrm{a}$

11. de Bang TC, Husted S. Lanthanide elements as labels for multiplexed and targeted analysis of proteins, DNA and RNA using inductively-coupled plasma mass spectrometry, Trends in Anal Chem 2015;72:45-52. doi: 10.1016/j.trac.2015.03.021

12. El-Khatib AH, Esteban-Fernández D, Linscheid MW. Dual labeling of biomolecules using MeCAT and DOTA derivatives: application to quantitative proteomics. Anal Bioanal Chem 2012;403:2255-67. doi: 10.1007/s00216-012-5910-1

13. Zhang $\mathrm{C}$, Wu F, Zhang $\mathrm{Y}$, Wang $\mathrm{X}$, Zhang $\mathrm{X}$. A novel combination of immunoreaction and ICP-MS as a hyphenated technique for the determination of thyroid-stimulating hormone (TSH) in human serum. J Anal At Spectrom 2001;16:1393-6. doi: 10.1039/B106387C

14. Zhang C, Zhang Z, Yu B, Shi J, Zhang XR. Application of the biological conjugate between antibody and colloid Au nanoparticles as analyte to inductively coupled plasma mass spectrometry. Anal Chem 2002;74:96-9. doi: 10.1021/ac0103468

15. Baranov VI, Quinn Z, Bandura DR, Tanner SD. A sensitive and quantitative element-tagged immunoassay with ICPMS detection. Anal Chem 2002;74:1629-36. doi: 10.1021/ac0110350

16. Bradbury A, Plückthun A. Reproducibility: Standardize antibodies used in research. Nature. 2015;518(7537):27-9. doi: 10.1038/518027a.

17. Careri M, Elviri L, Mangia A. Element-tagged immunoassay with inductively coupled plasma mass spectrometry for multianalyte detection. Anal Bioanal Chem 2009;393:57-61. doi: 10.1007/s00216-008-2419-8

18. Liu Z, Li X, Xiao G, Chen B, He M, Hu B. Application of inductively coupled plasma mass spectrometry in the quantitative analysis of biomolecules with exogenous tags: A review, Trends in Anal Chem 2017;93:78-101. doi: 10.1016/j.trac.2017.05.008 19. Tanner SD, Baranov VI, Ornatsky OI, Bandura DR, George TC. An introduction to mass cytometry: fundamentals and applications. Cancer Immunol Immunother: CII. 2013;62:955-65. doi:10.1007/s00262-013-1416-8

20. Mueller L, Traub H, Jakubowski N, Drescher D, Baranov VI, Kneipp J. Trends in single-cell analysis by use of ICP-MS, Anal Bioanal Chem 2014;406:6963-77. doi: $10.1007 / \mathrm{s} 00216-014-8143-7$ 
21. Schwarz G, Mueller L, Beck S, Linscheid MW. DOTA based metal labels for protein quantification: a review. J Anal At Spectrom 2014;29:221-33. doi: $10.1039 / \mathrm{c} 3 \mathrm{ja} 50277 \mathrm{e}$

22. Majonis D, Herrera I, Ornatsky O, Schulze M, Lou X, Soleimani M, Nitz M, Winnik MA. Synthesis of a functional metal-chelating polymer and steps toward quantitative mass cytometry bioassays. Anal Chem 2010;82:8961-9. doi: $10.1021 / \mathrm{ac} 101901 \mathrm{x}$

23. Liu J-M, Yan X-P. Ultrasensitive, selective and simultaneous detection of cytochrome $\mathrm{c}$ and insulin based on immunoassay and aptamer-based bioassay in combination with $\mathrm{Au} / \mathrm{Ag}$ nanoparticle tagging and ICP-MS detection. J Anal At Spectrom 2011;26:1191-7. doi: 10.1039/c0ja00232a

24. Cruz-Alonso M, Fernandez B, Álvarez L, González-Iglesias H, Traub H, Jakubowski N, Pereiro R. Bioimaging of metallothioneins in ocular tissue sections by LA-ICP-MS using bioconjugated gold nanoclusters as specific tags. Microchim. Acta 2018;185:64 (9 pp). https://doi.org/10.1007/s00604-017-2597-1

25. Limbeck A, Galler P, Bonta M, Bauer G, Nischkauer W, Vanhaecke F. Recent advances in quantitative LA-ICP-MS analysis: challenges and solutions in the life sciences and environmental chemistry. Anal Bioanal Chem 2015;407:6593-617. doi: $10.1007 / \mathrm{s} 00216-015-8858-0$

26. Wang HAO, Grolimund D, Giesen C, Borca CN, Shaw-Stewart JRH, Bodenmiller B, Günther D. Fast chemical imaging at high spatial resolution by laser ablation inductively coupled plasma mass spectrometry. Anal Chem 2013;85:10107-16. doi: $10.1021 /$ ac400996x

27. Van Malderen SJM, Managh AJ, Sharp BL, Vanhaecke F. Recent developments in the design of rapid response cells for laser ablation-inductively coupled plasma-mass spectrometry and their impact on bioimaging applications. J Anal At Spectrom 2016;31:423-39. doi: 10.1039/C5JA00430F

28. Chang Q, Ornatsky OI, Siddiqui I, Loboda A, Baranov VI, Hedley DW. Imaging mass cytometry. Cytometry Part A 2017;91A:160-9. doi: 10.1002/cyto.a.23053

29. Giesen C, Wang HAO, Schapiro D, Zivanovic N, Jacobs A, Hattendorf B, Schüffler PJ, Grolimund D, Buhmann JM, Brandt S, Varga Z, Wild PJ, Günther D, Bodenmiller B. Highly multiplexed imaging of tumor tissues with subcellular resolution by mass cytometry. Nature Methods 2014;11:417-22. doi: 10.1038/nmeth.2869 
30. Konz I, Fernández B, Fernández ML, Pereiro R, Sanz-Medel A. Laser ablation ICPMS for quantitative biomedical applications. Anal Bioanal Chem 2012;403:2113-25. doi: 10.1007/s00216-012-6023-6

31. Pozebon D, Scheffler GL, Dressler VL. Recent applications of laser ablation inductively coupled plasma mass spectrometry (LA-ICP-MS) for biological sample analysis: a follow-up review. J Anal At Spectrom 2017;32:890-919. doi: $10.1039 / \mathrm{c} 7 \mathrm{ja} 00026 \mathrm{j}$

32. Sussulini A, Becker JS, Becker JS. Laser ablation ICP-MS: application in biomedical research. Mass Spectrom Rev 2017;36:47-57. doi: 10.1002/mas.21481

33 Stack EC, Wang C, Roman KA, Hoyt CC. Multiplexed immunohistochemistry, imaging, and quantitation: a review, with an assessment of Tyramide signal amplification, multispectral imaging and multiplex analysis. Methods. 2014;70(1):4658. doi: 10.1016/j.ymeth.2014.08.016

34 Matos LL, Trufelli DC, de Matos MG, da Silva Pinhal MA. Immunohistochemistry as an important tool in biomarkers detection and clinical practice. Biomark Insights. 2010;5:9-20.

35. Rodríguez-Menéndez S, Fernández B, García M, Álvarez L, Fernández ML, SanzMedel A, Coca-Prados M, Pereiro R, González-Iglesias H. Quantitative study of zinc and metallothioneins in the human retina and RPE cells by mass spectrometry-based methodologies. Talanta 2018;178:222-30. doi: 10.1016/j.talanta.2017.09.024

36. Taylor CR, Levenson RM. Quantification of immunohistochemistry-issues concerning methods, utility and semiquantitative assessment II. Histopathology 2006; 49:411-24. doi: 10.1111/j.1365-2559.2006.02513.x

37. Bonta M, Török S, Hegedus B, Döme B, Limbeck A. A comparison of sample preparation strategies for biological tissues and subsequent trace element analysis using LA-ICP-MS. Anal Bioanal Chem 2017;409:1805-14. doi: 10.1007/s00216-016-0124-6 38. Giesen C, Waentig L, Mairinger T, Drescher D, Kneipp J, Roos PH, Panne U, Jakubowski N. Iodine as an elemental marker for imaging of single cells and tissue sections by laser ablation inductively coupled plasma mass spectrometry. J Anal At Spectrom 2011;26:2160-5. doi: 10.1039/c1ja10227c

39. Frick DA, Giesen C, Hemmerle T, Bodenmiller B, Günther D. An internal standardisation strategy for quantitative immunoassay tissue imaging using laser 
ablation inductively coupled plasma mass spectrometry. J Anal At Spectrom 2015;30:254-9. doi: 10.1039/c4ja00293h

40. Hoesl S, Neumann B, Techritz S, Sauter G, Simon R, Schlüter H, Linscheid MW, Theuring F, Jakubowski N, Mueller L. Internal standardization of LA-ICP-MS immune imaging via printing of universal metal spiked inks onto tissue sections. J Anal At Spectrom 2016;31:801-8. doi: 10.1039/c5ja00409h

41. Mueller L, Herrmann AJ, Techritz S, Panne U, Jakubowski N. Quantitative characterization of single cells by use of immunocytochemistry combined with multiplex LA-ICP-MS. Anal Bioanal Chem 2017;409:3667-76. doi: 10.1007/s00216017-0310-1

42. Boutureira O, Bernardes GJ. Advances in chemical protein modification. Chem Rev 2015;115:2174-95. doi: 10.1021/cr500399p

43. deGruyter JN, Malins LR, Baran PS. Residue-specific peptide modification: A chemist's guide. Biochem 2017;56:3863-73. doi: 10.1021/acs.biochem.7b00536

44. Giesen C, Mairinger T, Khoury L, Waentig L, Jakubowski N, Panne U. Multiplexed immunohistochemical detection of tumor markers in breast cancer tissue using laser ablation inductively coupled plasma mass spectrometry. Anal Chem 2011;83:8177-83. doi: 10.1021/ac2016823

45. Ahrends R, Pieper S, Kühn A, Weisshoff H, Hamester M, Lindemann T, Scheler C, Lehmann K, Taubner K, Linscheid MW. A metal-coded affinity tag approach to quantitative proteomics. Mol Cell Proteomics 2007;6:1907-16. doi: 10.1074/mcp.M700152-MCP200

46. Schwarz G, Beck S, Weller MG, Linscheid MW. MeCAT-new iodoacetamide reagents for metal labelling of proteins and peptides. Anal Bioanal Chem 2011;401:1203-09. doi: 10.1007/s00216-011-5189-7

47. Waentig L, Roos PH, Jakubowski N. Labelling of antibodies and detection by laser ablation inductively coupled plasma mass spectrometry. PART III. Optimization of antibody labelling for application in a Western blot procedures. J Anal At Spectrom 2009;24:924-33. doi: 10.1039/b905224k

48. Waentig L, Jakubowski N, Roos PH. Multi-parametric analysis of cytochrome P450 expression in rat liver microsomes by LA-ICP-MS. J Anal At Spectrom 2011;26:310-9. doi: $10.1039 / \mathrm{c0ja00077a}$ 
49. Waentig L, Jakubowski N, Hardt S, Scheler C, Roos PH, Linscheid MW. Comparison of different chelates for lanthanide labeling of antibodies and application in a Western blot immunoassay combined with detection by laser. J Anal At Spectrom 2012;27:1311-20. doi: 10.1039/c2ja30068k

50. de Bang TC, P Pedas P, Schjoerring JK, Jensen PE, Husted S. Multiplexed quantification of plant thylakoid proteins on western blots using lanthanide-labeled antibodies and laser ablation inductively coupled plasma mass spectrometry (LA-ICPMS). Anal Chem 2013;85:5047-54. doi: 10.1021/ac400561q

51. Waentig L, Techritz S, Jakubowski N, Roos PH. A multi-parametric microarray for protein profiling: simultaneous analysis of 8 different cytochromes via differentially element tagged antibodies and laser ablation ICP-MS. Analyst 2013;138:6309-15. doi: $10.1039 / \mathrm{c} 3 \mathrm{an} 00468 \mathrm{f}$

52. Mueller L, Mairinger T, Hermann G, Koellensperger G, Hann S. Characterization of metal-tagged antibodies used in ICP-MS-based immunoassays. Anal Bioanal Chem 2014;406:163-9. doi: 10.1007/s00216-013-7416-х

53. Kanje S, Herrmann AJ, Hober S, Mueller L. Next generation of labelling reagents for quantitative and multiplexing immunoassays by the use of LA-ICP-MS. Analyst 2016;141:6374-80. doi: 10.1039/c6an01878e

54. Lou X, Zhang G, Herrera I, Kinach R, Ornatsky O, Baranov V, Nitz M, Winnik MA. Polymer-based elemental tags for sensitive bioassays. Angew Chem Int Ed 2007;46:6111-4. doi: 10.1002/anie.200700796

55. Müller SD, Diaz-Bone RA, Felix J, Goedecke W. Detection of specific proteins by laser ablation inductively coupled plasma mass spectrometry (LA-ICP-MS) using gold cluster labelled antibodies. J Anal At Spectrom 2005;20:907-11. doi: 10.1039/B504571A

56. Seuma J, Bunch J, Cox A, McLeod C, Bell J, Murray C. Combination of immunohistochemistry and laser ablation ICP mass spectrometry for imaging of cancer biomarkers. Proteomics 2008;8:3775-84. doi: 10.1002/pmic.200800167

57. Hare DJ, Lei P, Ayton S, Roberts BR, Grimm R, George JL, Bishop DP, Beavis AD, Donovan SJ, McColl G, Volitakis I, Masters CL, Adlard PA, Cherny RA, Bush AI, Finkelstein DI, Doble PA. An iron-dopamine index predicts risk of parkinsonian neurodegeneration in the substantia nigra pars compacta. Chem Sci 2014;5:2160-9. doi: $10.1039 / \mathrm{c} 3 \mathrm{sc} 53461 \mathrm{~h}$ 
58. Paul B, Hare DJ, Bishop DP, Paton C, Nguyen VT, Cole N, Niedwiecki MM, Andreozzi E, Vais A, Billings JL, Bray L, Bush AI, McColl G, Roberts BR, Adlard PA, Finkelstein DI, Hellstrom J, Hergt JM, Woodhead JD, Doble PA. Visualising mouse neuroanatomy and function by metal distribution using laser ablation-inductively coupled plasma-mass spectrometry imaging. Chem Sci 2015;6:5383-93. doi: $10.1039 / \mathrm{c} 5 \mathrm{sc} 02231 \mathrm{~b}$

59. Li J, Zhu J-J, Xu K. Fluorescent metal nanoclusters: From synthesis to applications. Trends in Anal Chem 2014; 58;90-8. doi: 10.1016/j.trac.2014.02.011

60. Zhang L, Wang E. Metal nanoclusters: New fluorescent probes for sensors and bioimaging. Nano Today 2014;9:132-57. doi: 10.1016/j.nantod.2014.02.010

61. Alonso MC, Trapiella-Alfonso L, Fernández JMC, Pereiro R, Sanz-Medel A. Functionalized gold nanoclusters as fluorescent labels for immunoassays: application to human serum immunoglobulin E determination. Biosens Bioelectron 2016;77:1055-61. doi: 10.1016/j.bios.2015.08.011

62. Díez I, H. A. Ras RHA. Fluorescent silver nanoclusters. Nanoscale (2006)2011;3:1963-70. doi: 10.1039/C1NR00006C

63. Fernández JF, Trapiella-Alfonso L, Costa-Fernández JM, Pereiro R, Sanz-Medel A. Aqueous synthesis of near-infrared highly fluorescent platinum nanoclusters. Nanotechnology 2015;26:215601 (7pp). doi:10.1088/0957-4484/26/21/215601

64. Buckle T, van der Wal S, van Malderen SJM, Müller L, Kuil J, van Unen V, Peters RJB, van Bemmel MEM, McDonnell LA, Velders AH, Koning F, Vanhaeke F, van Leeuwen FWB. Hybrid imaging labels: providing the link between mass spectrometrybased molecular pathology and theranostics. Theranostics 2017;7:624-33. doi: $10.7150 /$ thno. 17484

65. Yang B, Zhang Y, Chen B, He M, Yin X, Wang H, Li X, Hu B. A multifunctional probe for ICP-MS determination and multimodal imaging of cancer cells. Biosens Bioelectron 2017;96:77-83. doi: 10.1016/j.bios.2017.04.041

66. Ruhe L, Ickert S, Beck S, Linscheid MW. A new strategy for metal labeling of glycan structures in antibodies. Anal Bioanal Chem 2018;410:21-5. doi: $10.1007 / \mathrm{s} 00216-017-0683-1$

67. Beck A, Goetsch G, Dumontet C, Corvaïa N. Strategies and challenges for the next generation of antibody-drug conjugates. Nature Reviews Drug Discovery 2017; 16: 315-37. doi: 10.1038/nrd.2016.268 
68. Marquez BV, Ikotun OF, Zheleznyak A, Wright B, Hari-Raj A, Pierce RA, Lapi SE. Evaluation of $89 \mathrm{Zr}$-pertuzumab in breast cancer xenografts. Mol Pharmaceutics 2014; 11:3988-95. doi: 10.1021/mp500323d

69. Zhang S, Zhang S, Zhang X, Liu R. Analysis of proteins and DNAs using inductively coupled plasma mass spectrometry and elemental tagging. Encyclopedia of Analytical Chemistry: Applications, Theory and Instrumentation, 2018;1-45. doi: 10.1002/9780470027318.a9639 
Table 1. Requirements and steps to follow for absolute quantitative mapping of specific proteins in biological tissues by elemental mass spectrometry.

\begin{tabular}{|c|c|c|}
\hline \multicolumn{2}{|r|}{ Requirements } & Steps to follow \\
\hline 1 & $\begin{array}{l}\text { Elements not detected in the biological } \\
\text { tissue to be analysed are } \\
\text { recommended for labelling }\end{array}$ & $\begin{array}{l}\text { It should be checked that the element to } \\
\text { be used as chemical reporter is not } \\
\text { present at detectable levels in the native } \\
\text { tissue. }\end{array}$ \\
\hline 2 & $\begin{array}{l}\text { Compromise between label size and } \\
\text { amplification provided }\end{array}$ & $\begin{array}{l}\text { It should be selected a label providing } \\
\text { high amplification, but small enough to } \\
\text { not affect the recognition capabilities of } \\
\text { the antibody. }\end{array}$ \\
\hline 3 & $\begin{array}{l}\text { Number of atoms of the detected } \\
\text { element (or isotope) per label should } \\
\text { be known, as well as the concentration } \\
\text { of the label in the procedure of } \\
\text { antibody labelling }\end{array}$ & $\begin{array}{l}\text { Combination of studies with TEM and } \\
\text { ICP-MS can provide the number of } \\
\text { atoms per label as well as the } \\
\text { concentration of the label in the labelling } \\
\text { solution. }\end{array}$ \\
\hline 4 & $\begin{array}{l}\text { Antibody labelling conditions as mild } \\
\text { as possible }\end{array}$ & $\begin{array}{l}\text { It should be searched for efficient } \\
\text { labelling conditions not affecting the } \\
\text { antibody reactivity. }\end{array}$ \\
\hline 5 & $\begin{array}{l}\text { Reproducible antibody labelling } \\
\text { procedures producing stable bonds } \\
\text { between label and protein }\end{array}$ & $\begin{array}{l}\text { Experiments should be done to check } \\
\text { reproducibility. Also, stability of the } \\
\text { bond should be investigated along time } \\
\text { and under different media. }\end{array}$ \\
\hline 6 & $\begin{array}{l}\text { Unlabelled antibodies should not be } \\
\text { present after the antibody labelling } \\
\text { process, or at least, the labelling yield } \\
\text { should be known }\end{array}$ & $\begin{array}{l}\text { To achieve this, it is convenient to use an } \\
\text { excess of the label in the labelling } \\
\text { procedure of the antibody. Also, different } \\
\text { strategies can be studied for removing } \\
\text { the excess of unconjugated antibody (e.g. } \\
\text { by chromatography or ultrafiltration) }\end{array}$ \\
\hline 7 & $\begin{array}{l}\text { Aggregation of labelled antibodies } \\
\text { should be avoided }\end{array}$ & $\begin{array}{l}\text { This should be checked with gel } \\
\text { electrophoresis, fluorescence microscopy } \\
\text { and electron microscopy techniques. }\end{array}$ \\
\hline 8 & $\begin{array}{l}\text { The number of labels per available } \\
\text { antibody should be known }\end{array}$ & $\begin{array}{l}\text { The stoichiometry should be determined } \\
\text { by ICP-MS and ELISA. }\end{array}$ \\
\hline 9 & $\begin{array}{l}\text { Quantitative immunohistochemistry } \\
\text { processes }\end{array}$ & $\begin{array}{l}\text { The labelled antibody should be in } \\
\text { excess and the interaction with the } \\
\text { specimen should be kept during a time } \\
\text { long enough. }\end{array}$ \\
\hline 10 & $\begin{array}{l}\text { Detection system with high sensitivity, } \\
\text { structure-independent response and } \\
\text { wide dynamic linear range }\end{array}$ & $\begin{array}{l}\text { A detection system such as laser ablation } \\
\text { coupled to ICP-MS should be used. }\end{array}$ \\
\hline
\end{tabular}


a)<smiles>O=C(O)CN(CCN(CC(=O)O)CC(=O)O)CCN(CC(=O)O)CC(=O)O</smiles>

b)

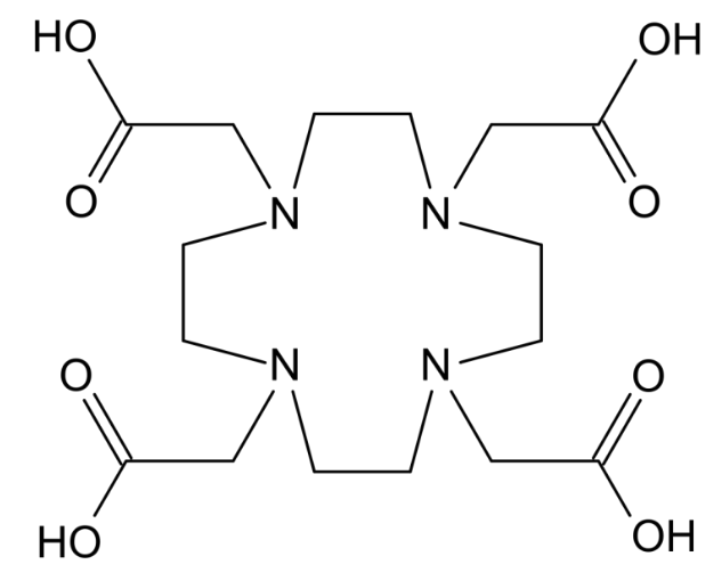

c)

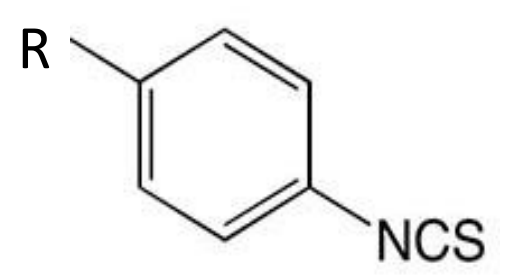

d)<smiles>[R]N1C(=O)C=CC1=O</smiles>

Figure 2 
a)

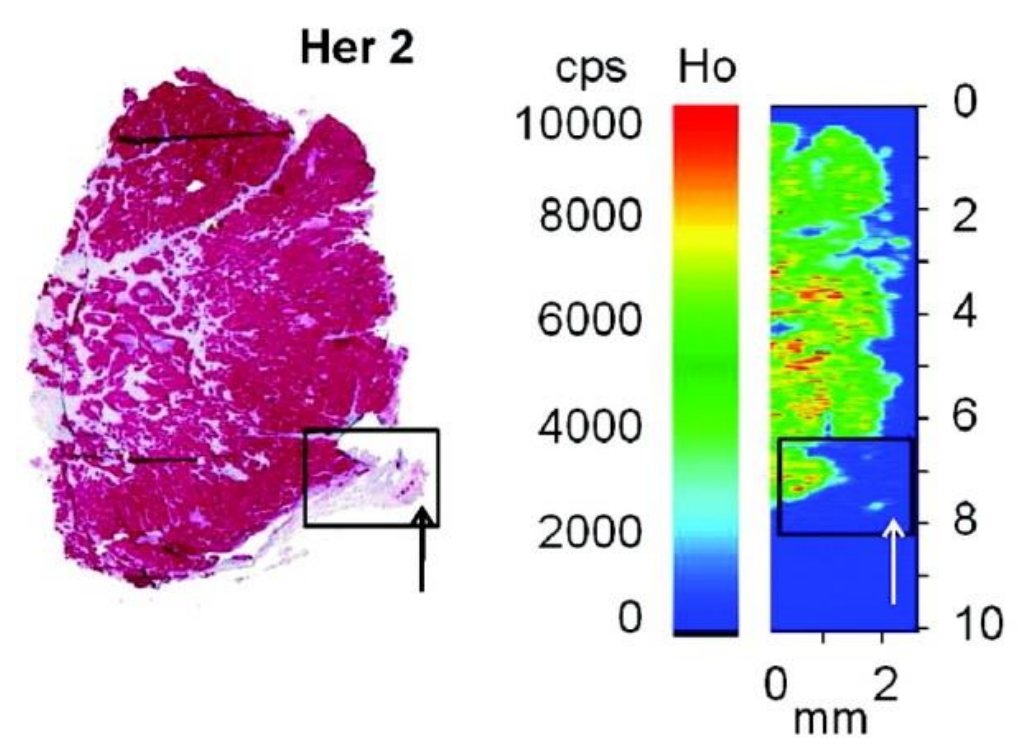

b)

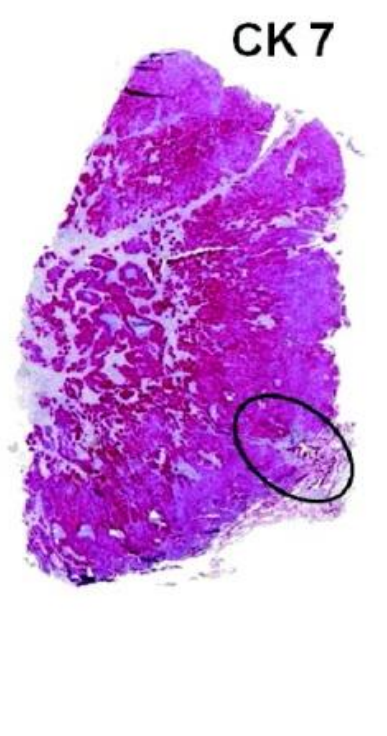

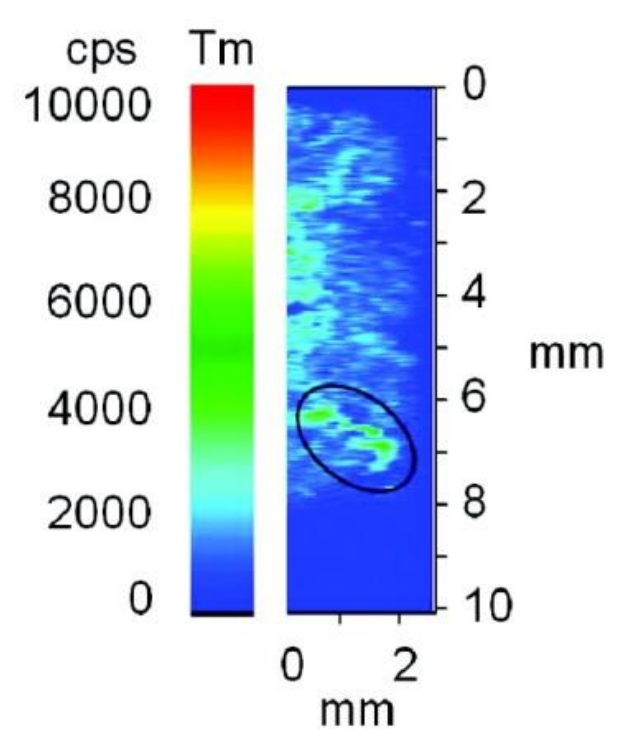

Figure 3 


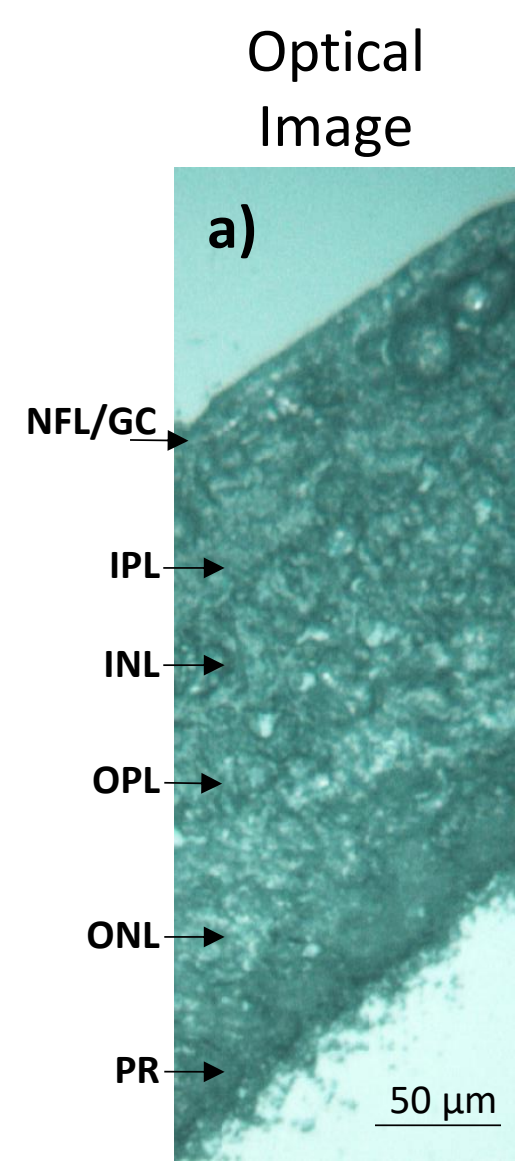

Fluorescence

mapping

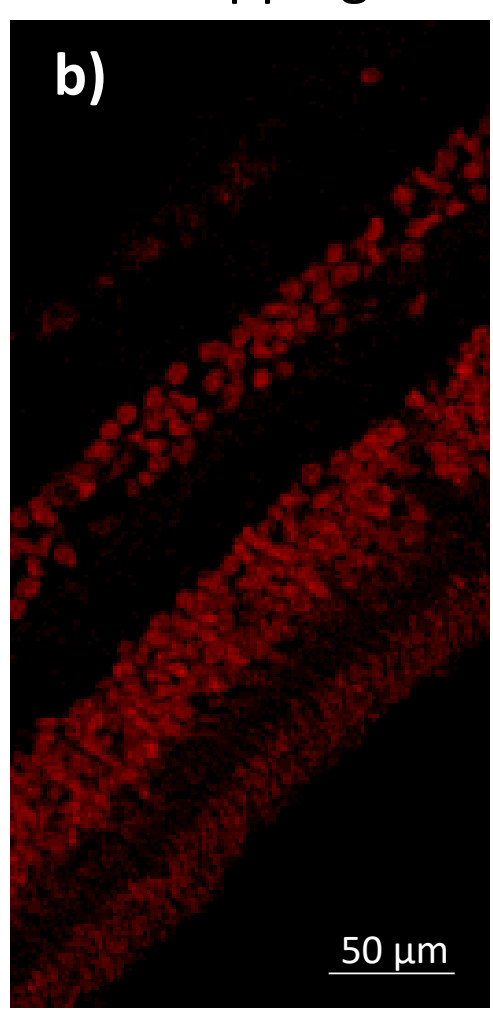

LA-ICP-MS

mapping

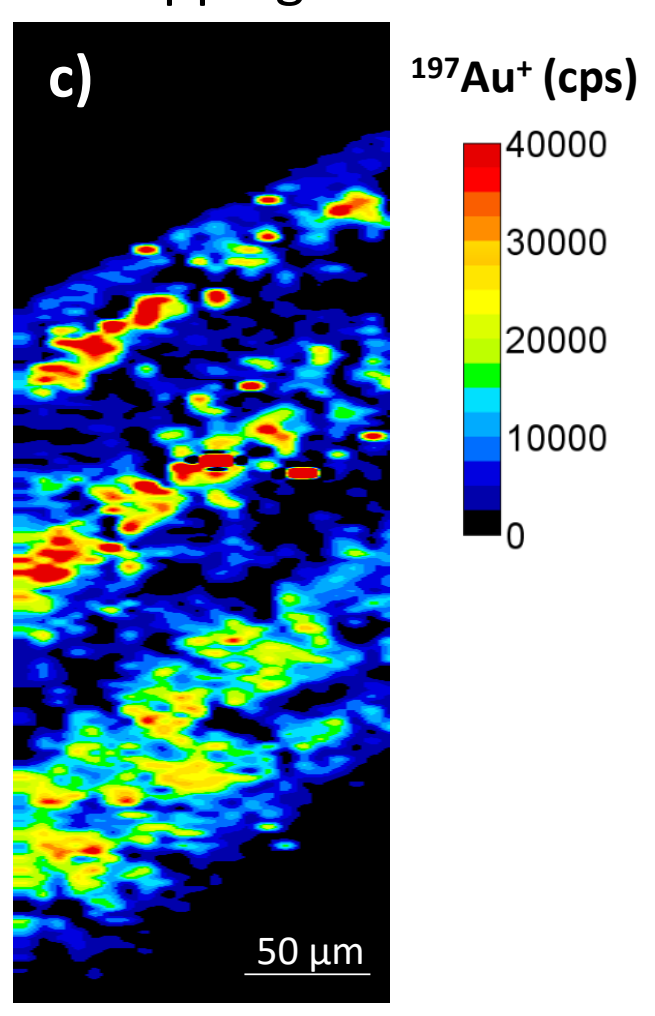

Figure 4 